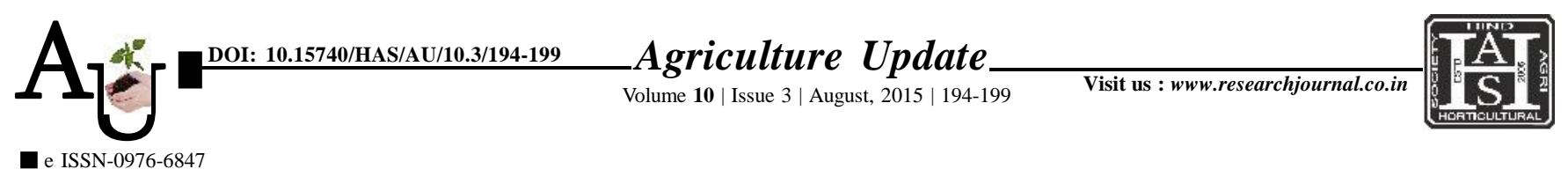

\title{
Rевевсн автіск: Content analysis of agricultural information in Agrowon newspaper
}

\author{
SARIKA PULATE, D.D. SURADKAR AND K. VENKATESHA
}

Article Chronicle: Received :

16.04.2015;

Revised :

03.07.2015;

Accepted :

04.08.2015

SUMMARY : In Agrowon newspaper among the agricultural information, other agricultural articles topped $(72.21 \%)$ in that general marketing topped $(21.09 \%)$ followed by the meteorology $(20.26 \%)$ and on third position miscellaneous information $(15.75 \%)$. The crop husbandry information was on the second position, nearly one seventh (13.55\%) of the agricultural information appeared in Agrowon in which cash crop information topped $(37.97 \%)$ followed by the cereals $(20.86 \%)$. The animal husbandry information $(10.18 \%)$ in which general animal husbandry information topped $(29.18 \%)$ in the total number of animal husbandry information in Agrowon newspaper followed by cow $(16.73 \%)$, very less $(4.06 \%)$ information was appeared on agricultural policies.

How to cite this article : Pulate, Sarika, Suradkar, D.D. and Venkatesha, K. (2015). Content analysis of agricultural information in Agrowon newspaper. Agric. Update, 10(3): 194-199.

KEY WoRds:

Content analysis, Agricultural

information, Agrowon newspaper 